\title{
Sn (Cu) skarnoid-type mineralization in the Visean Trournaisian volcano- sedimentary series of the northeastern Massif Central, implications on the conceptual model.
}

\section{STANISLAS SIZARET}

Institut des Sciences de la Terre d'Orléans

Presenting Author: stanislas.sizaret@univ-orleans.fr

The metallogenic model of Sn-W mineralization involves hydrothermal circulations in the vicinity of the roofs of granite bodies (eg: apex, undulations, dike systems, network of faults, etc.). In general, the models suggest a depth emplacement between 3 and $5 \mathrm{~km}$ and the structures inherited from surface volcanic systems are neglected because they are not observable. In variscan belt, the caldera of Teplice, within the Bohemian massif, is known to be earlier compared to the magmatic manifestation related to Sn-W mineralization (e.g. Casas-Garcia et al., 2019). In the Massif Central, the relationship between the volcanic edifices and mineralizations has not been studied. In the western part, the $\mathrm{Sn}-\mathrm{W}$ deposits are related to granitic plutons emplaced from the Visean to the Permian times (Harlaux et al., 2018). However, in this area, there is no witness of volcanic activity. In the northeastern part, no age is known for the Sn-W mineralizations, while in this region the series of the 'Tufs Anthracifères" (Tournaisien - Visean 345-325 Ma) host igninbrites and could have formed a favorable calderic environnent for the Sn W mineralizations.

In this study we propose to describe the mineralization of Châtelet in the north-east of the Massif Central near the aluminopotassic granite of Folin dated at $337 \mathrm{Ma}+/-12 \mathrm{Ma}$, and hosted in Tournaisian sediments and Visean formation ignimbritic. The mineralogy of the Chaletet showing suggests the formation of a $\mathrm{Sn}(\mathrm{Cu})$ skarnoid. The relative chronology between granite, sediments, ignimbrites and mineralization will be discussed in order to propose a conceptual model that can account for the observations.

Casas-Garcia R., Rapprich V., Breitkreuz C., Svojtka M., Lapp M., Stanek K., Hofmann M. Linnemann U., (2019). Lithofacies architecture, composition, and age of the Carboniferous Teplice rhyolite (German-Czechborder) : Insights into the evolution of the Altenberg-Teplice Caldera. Journal of Volcanology and geothermal research, 386, 106662.

Harlaux M. Romer R.-L., Mercadier J., Morlot C., Marignace C., Cuney M., (2018). 40 Ma of hydrothermal W mineralization during the Variscan orogenic evolution of the French Massif Central revealed by $\mathrm{U}-\mathrm{Pb}$ dating Wolfrmaite. Mineralium Deposita, $53: 21-51$. 